\title{
Refik Fersan'ın Bestecilik Yönü ve Arazbarbuselik Saz Semaisinin İncelenmesi
}

\section{Refik Fersan as a Composer and an Analysis on Arazbarbuselik Instrument Semai}

\section{Selahaddin Abidin}

Müzik Öğretmeni, Manisa İMKB Mesleki ve Teknik Anadolu Lisesi

email: selahaddinabidin@gmail.com (DORCID ID: https://orcid.org/0000-0002-7256-0539

\section{Cabbar Sami Büyüköztekir}

Öğr. Gör., Ege Üniversitesi Devlet Türk Musikisi Konservatuvarı

email: samibuyukoztekir@gmail.com (DORCID ID: https://orcid.org/0000-0002-7350-1725

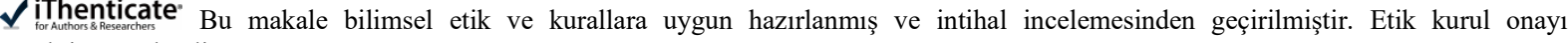 \\ gerektirmemektedir. \\ Atıf (APA 7)/To cite this article \\ Abidin, S., \& Büyüköztekir, C. S. (2021). Refik Fersan’ın bestecilik yönü ve arazbarbuselik saz semaisinin incelenmesi. Atatürk Üniversitesi \\ Güzel Sanatlar Enstitüsü Dergisi, 27(47), 509-519. https://doi.org/10.35247/ataunigsed.944140 \\ Makale Gönderim Tarihi/Received: 02/06/2021 \\ Makale Kabul Tarihi/Accepted: 21/07/2021 \\ Makale Yayun Tarihi/Published: 28/10/202
}

Review Article / Derleme Makale

$\ddot{O} z$

Bu çalışmada Refik Fersan'ın daha önce incelenmemiş olan Arazbarbuselik Saz Semaisi'nin makam analizi yapılmaktadır. Bu eserin seçilmesinin sebepleri, bu eserin tambur için yazılmıs en zor eserlerden biri olması, Türk Müziği ile Batı Müziğinin sentezini yapan önemli eserlerden bir tanesi olarak kabul edilmesi ve eserin normal saz semaisi formlarının dışında olması olarak sıralanabilir. Bu çalışma ile Türk Müziği'nde önemli bir yere sahip bestekar ve tambur üstadı Refik Fersan'ın önemli bir eserinin incelemesinin Türk Müziği literatürüne kazandırılması amaçlanmaktadır. Makam analizi yapmak için eser ölçü ölçü çözümlenmek sureti ile ele alınmaktadır. Ayrıca bestekarın yaşadığı döneme ait bilgi verebilmek için kaynak tarama yönteminden faydalanılmıștır. Refik Fersan'ın üstadı olduğu tambur, gelenekte ağırbaşlı çalınan bir enstrüman olmasına rağmen, Tamburi Cemil Bey ile daha dinamik bir çalım șekli almış, öğrencisi olan Refik Fersan da çalışmada incelenen eseriyle tamburu, sazın sınırlarını zorlayan bir noktaya taşımıştır. Eserde, cok az kullanılan bir makam olan Arazbarbuselik makamının bestekar tarafindan çok iyi bir şekilde işlenmesi, günümüzdeki sanatçılara ve icracılara makamların daha iyi anlatılması ve az kullanılan makamların kullanımının özendirilmesi açısından bir örnek oluşturmaktadır. Bu çalışmada nitel bir araştırma yöntemi olarak Refik Fersan'ın eserinin Ferhat Devecioğlu tarafindan notaya alınmış şekli kullanılmıştır.

Anahtar kelimeler: Refik Fersan, Arazbarbuselik Saz Semaisi, Tambur

\begin{abstract}
In this study, maqam analysis for Refik Fersan's Arazbarbuselik Saz Semai, which has not been studied before, is realized. The reasons for choosing this piece can be listed as the fact that this piece is one of the most difficult works written for the tambour, it is considered as one of the important pieces that synthesize Turkish and Western Music, and that the piece is different from the normal saz semai forms. To make a maqam analysis, the work is handled by analyzing it in measures. In addition, the method of source research was used to give information about the period in which the composer lived. Although the tambour, mastered by Refik Fersan, is an instrument played dignified in tradition, it took a more dynamic playing style with Tamburi Cemil Bey, and his student, Refik Fersan, carried it to a point that pushes the boundaries of the instrument with the work examined in the study. The composition of Arazbarbuselik maqam by the composer, which is a rarely used maqam, is an example to explain the maqams better to contemporary artists and performers and to encourage the use of less used maqams. In this study, as a qualitative research method, the version of Refik Fersan's work, which was notated by Ferhat Devecioğlu, was used.
\end{abstract}

Keywords: Refik Fersan, Arazbarbuselik Instrument Semai, Tambour

\section{Giriş}

Türk Müziği'ne emek vermiş, eserleriyle katkıda bulunmuş, enstrüman icralarıyla başka sanatçılara hocalık ve önderlik yapmış pek çok önemli sanatçımız bulunmaktadır. Bunların arasında özellikle bir enstrüman üzerinde ustalaşmış olanlar, icralarındaki tavır ile tanınmakta ve örnek alınmaktadırlar. Önemli bestelere imza atmış olan sanatçılarımız ise bestelerinin kuşaktan kuşağa aktarılması ile ölümlerinden sonra da Türk Müziği’ne katkıda bulunmaya devam etmektedirler. Bu çalışmada eser incelemesi yapılan Refik Fersan ise bu iki önemli özelliği kendinde birleştirebilmeyi başarmış büyük bir tambur üstadı ve bestekar olarak Tük Müziği'nde önemli bir yere sahip olmuş bir sanatçıdır. Hem tambur icrasındaki yüksek tekniği hem de eserlerindeki duygu güzelliği, sanatçının ve eserlerinin ele alınmasını ve detaylı incelenmesini gerektirmektedir.

Refik Fersan ile ilgili yapılan literatür taramasında, sanatçının bazı eserlerinin incelendiği çalışmalara rastlanmaktadır. Örneğin, (Başara, 2013) çalışmasında Refik Fersan'ın altı adet eserini vezin-usûl açısından 
incelemiş ve Fersan'ın, alışılmış uygulamaları prozodiye uygun olarak kullandığı, bazı bestecilere örnek olduğu sonucuna ulaşmıştır.

Refik Fersan'ın hayatını ve eserlerini konu alan literatürdeki önemli çalışmalardan biri (Saraç, 1993) tarafından bestekarın on adet sözsüz eserinin incelendiği yüksek lisans tezidir. Bu tezde, Arazbarbuselik Saz Semaisi incelenmemiştir.

Bu çalışmanın yazarlarından birine ait başka bir eser inceleme çalışmasında keman sanatçısı ve bestekâr Hasan Soysal'ın farklı formlardaki ödüllü eserlerinin makam ve usul yönünden incelenmesi gerçekleştirilmiş (Abidin ve Çelik, 2020), bu yeni çalışmada ise eser inceleme çalışmalarını bir adım ileriye taşıyabilmek amacı ile teknik zorlukları fazla olan ve daha önce herhangi bir akademik çalışmada ele alınmamış Refik Fersan'ın Arazbarbuselik Saz Semaisi seçilmiştir.

İnceleme için bu eserin seçilmiş olmasının iki temel sebebi bulunmaktadır. Bunlardan birincisi, bu eserin tambur için yazılmış en zor eserlerden biri olması ve eserin Türk Müziği ile Batı Müziğinin sentezini yapan önemli eserlerden bir tanesi olarak kabul edilmesidir. Melodi gidişatı bakımından Batı Müziğine benzemekte ve özellikle ikinci hanesinde tamamen batı müziğinin tekniği ve melodi yapıları kullanılmaktadır. Bu eserin incelenmesinin ikinci nedeni de eserin normal saz semaisi formlarının dışında olmasıdır. Çünkü eserde, her haneden sonra ve teslimden önce (normalde saz semailerinde yer almayan) Tertip adı verilen bölüm çalınmaktadır.

Çalışma şu bölümlerden oluşmaktadır. Giriş bölümünde analizi yapılmak üzere hangi eserin seçildiği nedenleriyle birlikte anlatılmakta, ikinci bölümde ise çalışmada eser analizi için izlenen yöntemler açıklanmaktadır. Üçüncü bölümde bulgular ve eser analizini içeren yorum bölümü ele alınmış olup, dördüncü bölümde ise çalışmanın sonuçları açıklanmaktadır.

\section{Yöntem}

Çalışmada Refik Fersan'ın Arazbarbuselik Saz Semaisi'nin makamsal analizi gerçekleştirilmektedir. Eser incelemesi yapabilmek için parçanın daha küçük bölümler halinde ele alınması ve bu bölümlerin birbiri ile uyumunun da çözümlenmesi gerekir. Türk Müziğinde eser incelemesi yapmak için eserin ele alınabilecek en küçük birimi ölçü olarak kabul edilmiştir. Bu bağlamda müzik eserinin analizi, müzikal yapının göreceli olarak daha basit bileşenlere ayrılarak incelenmesi olarak tanımlanabilir (Sadie, 2001, s. 526). Analiz, nesnel bir bakış açısıyla yapılmalı ve doğru bilgi ve birikim ile harmanlanmalıdır. Bir eser incelenirken, bestecisinin yaşadığı dönem ve o dönemin koşulları da dikkate alınmalıdır. (Bulur, 2019). Bu sebeple bu çalışmada eser analizi öncesinde bestekarın yaşam öyküsüne kısaca değinilmiş, eserin yaratıcısının içinde bulunduğu koşulların anlaşılması amaçlanmıştır.

Bu araştırma, bestekar ve tambur üstadı Refik Fersan'ı tanıtmak, yaşadığı dönemin özelliklerinin eserlerindeki yansımasını tespit etmek ve Türk Müziğgi eseri içerisinde Batı Müziği nağmelerini ustalıkla kullanabildiğini gösteren önemli bir bestesini incelemek amacıyla yapılmıştır. Tarama modeli kullanılarak bestekarın yaşamına ilişkin yazılı literatürdeki kaynakların incelemesi yapılmıştır. Ayrıca eser incelemesi çerçevesinde, bestekarın sazındaki hakimiyetinin eserine yansımaları teknik açıdan ele alınmış ve eserin zorluk ve teknik yönünden üst düzeyde olan bölümlerine vurgu yapılmıştır.

Bestekarın yaşadığı dönem ve hayatı hakkında bilgi toplayabilmek için tarama metodu ile tarih kaynakları araştırılmış, bu sayede çalışmaya disiplinler arası bir boyut katılması hedeflenmiştir. Ayrıca nitel bir araştırma yöntemi olarak Refik Fersan'ın eserinin Ferhat Devecioğlu tarafından notaya alınmış şekli üzerinde makam analizi gerçekleştirilmiştir.

\section{Bulgular}

$\mathrm{Bu}$ bölümde, eseri incelenecek olan bestekarın içinde bulunduğu yaşam koşullarının doğru anlaşılabilmesi bakımından ilk olarak bestekarın hayatına değinilmekte, bölümün devamında bestecilik yönü ve eserlerine ilişkin bilgiler açıklanmaktadır.

\subsection{Refik Fersan'm Hayatı}

Refik Fersan, 1893 yılında İstanbul Şehzadebaşı’nda doğmuştur. Ailesinde, aile bireylerinin hepsinin bir müzik aleti çalması geleneği vardır. Refik Bey bir yaşındayken babasının ölmesi üzerine, annesi ile yakınları olan Faik Bey'in evine taşınmıştır. Burada aristokrat bir çevrede büyüme firsatı olmuştur. Dolayısıyla müzikle ilgilenmeye başladığı andan itibaren, ait olduğu üst tabakanın müziğini yapmaya başlamıştır. Faik Bey’in yalısında, haftanın belli günlerinde Tamburi Cemil Bey, Leon Hancıyan, Lâvtacı Andon, Rahmi Bey, Lem'î Atlı, Neyzen Aziz Dede gibi ustalar yetenekli kalfa ve cariyelere ders vermektedir. Refik Bey de bu müzikle iç içe ailenin bir parçası olarak önce ud çalmaya çalışır. Fakat bir süre sonra tambur çalmaya karar verir. Böylece 12 yaşında Tamburi Cemil Bey’den ders almaya başlar. 5 yıl boyunca hocası ile çalışmıştır. Aynı anda Leon Hancıyan'dan usûl dersleri almaktadır. Refik Fersan, Tamburi Cemil Bey’in yetiştirdiği 5 tamburiden biridir. Diğer öğrencileri, Cemil Bey’in ablası Beyhan Hanım'ın oğlu Hikmet Bey, Kadı Fuat Efendi, Faize Ergin ve Tahsin Bey’dir. 
Refik Bey müzik eğitiminin yanında Robert Koleji ve Galatasaray Lisesi'ne de devam etmektedir. Tevfik Fikret'ten ve Ahmet Rasim Bey'den Fransızca, edebiyat ve İngilizce öğrenir.

1913 yılında Fahire Fersan ile evlenir. O dönemde Cenevre'ye gidecekleri için düğünleri Cenevre'de olur. Refik Bey burada kimya öğrenimine başladıysa da bu eğitimini tamamlayamamıştır.

Refik Bey, büyüdüğü ortamın sanatkârların, ilim adamlarının ve zamanın üst düzey bürokratlarının uğrak yeri olması nedeniyle, bu ortama uygun eserler üretmiştir. Bu nedenle Refik Fersan'ın müziği, yetiştiği çevrenin zevk aldığı, yani aristokrat sınıfa hitap eden bir müziktir.

Refik - Fahire çiftinin 1917 yılından sonraki hayatı, çocukluk ve ilk gençlik yıllarındaki rahat yaşamın tam tersi olmuştur. Aile reisi Faik Bey, 1. Dünya Savaşı sırasında tüm servetini kaybetmiştir. Bu nedenle Refik-Fahire çiftinin bir zamanlar aristokrat aile gelenekleri icabı başlatıldıkları müziği sonradan meslek edinmelerinin sebebi geçim derdine düşmüş olmalarıdır.

Refik Bey 1917 yılında Darülelhan'a girer. Darülelhan, tambur, kemençe, ney, keman, santur, lavta, ud sazlarının öğretildiği bir kurumdur ve Cumhuriyet'in ilanından sonra İstanbul Konservatuvarı'na dönüşmüştür. Dârülelhan'ın amacı solist ve saz icracısı yetiştirmektir. Dârülelhan kurulan ilk resmî müzik okulu olması, Türk Müziği eğitiminin evrensel eğitim yöntemleriyle desteklenerek verilmesi bakımından da önemli bir kurumdur. $\mathrm{Bu}$ okulda, kuruluşundan itibaren hem Türk hem de Batı Müziği’nin birlikte öğretilmesi düşünülmüştür (Behar, 2008). Okul ilk kurulduğunda İsmail Hakkı Bey, Zekâîzâde Ahmet Efendi, Leon Hancıyan, Ziya Santur, Refik Fersan, Dürrü Turan kadroda görev yapmıştır (Özcan, 1995). Refik Bey burada "tambur muallimi” olarak öğretim üyeleri arasına katılmıştır. 1918 yılında askerlik hizmetini yapmak üzere Mızıka-i Humayun’a tayin olur. Aynı yıl içerisinde İsmail Hakkı Bey yönetiminde ilk konserini verir.

Darülelhan'da çalışırken Refik Fersan'dan bir metot yazması istenir. Refik Bey bir yıl gibi bir sürede dört bölümden oluşan bir tambur metodu ile nazariyat kitabı yazar. Bu metotta bütün makamlarla usuller, örnekler verilerek, şedleri ve transpozisyonları ile ayrı ayrı gösterilmiştir. Eser çok beğenilir ve hemen basılıp çoğaltılmasına karar verilir. Fakat bu eser bir şekilde ortadan kaybolur (Akçay, 2005). Refik Fersan o kadar üzülür ki otuz yıl gibi bir süre boyunca tekrar yazmaya cesaret edemez. 1948'de Şam'da bulunduğu sırada bir nazariyat kitabı daha yazmış, fakat bu kitap da Arap - İsrail savaşının çıkmasıyla şehirden aceleyle ayrıldığı için kaybolmuştur.

Refik Bey, Türkiye Cumhuriyeti’nin kuruluşundan sonra, 1924 yılında “Cumhurbaşkanlığı Fasıl Heyeti Şefi”" olur. 1927 yılına kadar çalıştıktan sonra sağlık nedenleri ile bu görevinden ayrılarak İstanbul'a yerleşir. Çankaya Köşkü’nde çalıştı̆̆ yıllarda, başbakan İsmet İnönü’nün Yunanistan'a yaptığı bir geziye katılır. O yıllarda bestelemiş olduğu Rast “Medhal”'i Yunanistan'da armonize edilerek çalınmış ve Yunanlılar bu sayede Refik Bey'i 1931 yılında keşfetmişlerdir.

Refik Fersan, İstanbul'a yerleştikten sonra, Darülelhan'da tanıştığ 1 Münir Nureddin Selçuk ile serbest çalışma hayatına atılmışıır. Beraber plak çalışmaları yapmışlar ve eşi Fahire Fersan ile Münir Nurettin Selçuk’un konserlerine doldurmuş olduğu plaklara eşlik etmiştir.

1927 yılında radyoda ilk konserini verir. İkinci konserinde kendisine eşi, üçüncü konserinde ise Münir Nurettin eşlik etmiştir. Sonrasında, haftada 2-3 gün olmak üzere Münir Nurettin ile konser vermeye devam ederler. 1937 yılına kadar İstanbul Radyosu'nda görev yapmıştır. 1938 yılında Ankara Radyosu'nun hizmete açılması ile Ankara'ya gelmiş ve bir süre burada çalışmıştır. Daha sonra İstanbul'a dönerek İstanbul Belediye Konservatuarı İcra Heyeti'nde çalışır. Aynı zamanda "İlmi Kurul" başkanlığı yapmış ve Tasnif Heyeti'nde de çalışmıştır. 1960 yılında Radyo'dan ayrılır ve uzun süredir çekmekte olduğu bir akciğer rahatsızlığından dolayı, 13 Haziran 1965 tarihinde vefat eder.

Refik Bey'in anılarında en önemli yeri tutan olaylardan bir tanesinin Çankaya Köşkü'nde bulunduğu yıllarda büyük önder Atatürk'ün arzusu üzerine aynı gece çok kısa bir süre içerisinde Nikriz makamındaki saz semaisini bestelemesi ve yine ayn gece icra etmesidir. Atatürk özellikle eserin son bölümünden çok etkilenmiş̧ir.

\subsection{Refik Fersan'ın Bestecilik Yönü ve Eserleri}

Refik Fersan yirminci yüzyılın en önemli Türk Müziği bestekarlarından kabul edilmektedir. Refik Bey'in özellikle çalgısal eserlerdeki bestecilik yeteneği çok güçlüdür. Örneğin kırk dokuz makamı içinde barındıran bir Kâr-1 Natık bestelemiştir. Büyük, küçük her formda eser veren Refik Fersan'ın saz ve sözlü eserlerinde geleneklere bağlı kaldığı görülmekle birlikte, bir miktar yeniliğe taraftar bir orijinalite sezilir (Bardakçı, 1995). Refik Bey'e ait olan eserlerin formları, makamları ve eser sayıları Tablo 1'de verilmiştir (Muattar, 2014; Bardakçı, 1995). 
Tablo 1

Refik Fersan'ın Eserlerinin Formlara Göre Dă̆ılımı

\begin{tabular}{|c|c|c|}
\hline Form & Eser Sayısı & Makamları \\
\hline Mevlevi ayini & 2 & Rast, Selmek \\
\hline İlahi / Nefes & 7 & Buselik, Büzürg, Hüzzam, Mahur, Rast, Selmek \\
\hline Sirto & 3 & Acemașiran, Nikriz, Sultaniyegah \\
\hline Peşrev & 19 & $\begin{array}{l}\text { Acemaşiran, Acemkürdi, Besteısfahan, Eviç, Hicaz, Hicazkar, Karcığar, Kürdi, Mahur, } \\
\text { Nihavend, Nikriz, Rast, Sabazemzeme, Sultaniyegah, Şedaraban, Şehnazbuselik }\end{array}$ \\
\hline Saz Semaisi & 26 & $\begin{array}{l}\text { Acemaşiran, Acemkürdi, Arazbarbuselik, Bayatiaraban, Besteisfahan, Bestenigar, Evcara, } \\
\text { Hicaz, Hisar, Hüzzam, Karcığar, Kürdi, Mahur, Müstear, Neva, Nihavend, Nikriz, Rast, } \\
\text { Segâh, Selmek, Sultaniyegah, Suzinak, Tahir, Tahirbuselik, Yegah }\end{array}$ \\
\hline Oyun Havaları & 1 & Sultaniyegah \\
\hline Şarkı / Türkü & 206 & $\begin{array}{l}\text { Acemaşiran, Acemkürdi, Amberefşan, Bayatiaraban, Eviçbuselik, Ferahfeza, Ferahnak, } \\
\text { Gerdaniye, Gülizar, Hicaz, Hisarbuselik, Hüseyni, Hüzzam, Irak, Karcığar, Kürdilihicazkar, } \\
\text { Mahur, Mahurbuselik, Muhayyer, Neva, Nihavend, Nikriz, Pesendide, Rast, Saba, Segâh, } \\
\text { Selmek, Sultanibuselik, Suzinak, Şedaraban, Şehnazbuselik, Tahirbuselik, Tarzıkürdi, } \\
\text { Uşşak, Zavil }\end{array}$ \\
\hline Form & Eser Sayısı & Makamları \\
\hline Mevlevi ayini & 2 & Rast, Selmek \\
\hline İlahi / Nefes & 7 & Buselik, Büzürg, Hüzzam, Mahur, Rast, Selmek \\
\hline Sirto & 3 & Acemaşiran, Nikriz, Sultaniyegah \\
\hline
\end{tabular}

Refik Bey'in yukarıda belirtilenler dışında bestelemiş olduğu dokuz adet marş, dört adet reklam müziği, beş adet makamı belirtilmemiş fantezi ve makamı belirtilmemiş, notası bulunmayan veya son şekli verilmemiş pek çok eserinin olduğu bilinmektedir (Bardakçı, 1995).

Refik Fersan'ın en önemli eserleri arasında teknik bakımdan değeri yüksek ve ajeliteye dayalı olanları Arazbarbuselik Saz Semaisi, Nikriz Saz Semaisi, Hüzzam Saz Semaisi (Kaya, 2013), dört hane bir teslim şeklinde peşrev formu yapısında bestelenmiş olmasına rağmen ilk hanesi ve teslim bölümü Rast Medhal olarak icra edilen Musâhabât-1 Mûsikîye (Tüfekçioğlu, 2019) sayılabilir.

Refik Bey'in unutulmuş bir makam olan Selmek makamını kullanarak Mevlevi ayini bestelemiş olması, bu makamı eser vererek zenginleştirmesi bakımından önemli bir katkı olarak dikkati çekmektedir çünkü unutulmuş makamların seyir ve karakteristik özelliklerini çok iyi bilmektedir. Çok güçlü Hamparsum notası (Ak, 2015) bilgisine sahip olduğundan gerek Ankara Radyosu'nda gerekse İstanbul Belediye Konservatuarı'nda çalıştığı yıllarda bu nota ile yazılmış eski külliyatlardan birçok eserin batı notasına çevrilerek kazanılmasını sağlamıştır. Refik Bey İstanbul ve Ankara radyoları ile İstanbul Belediye Konservatuvarı'nda bulunduğu yıllarda çeşitli külliyatlar üzerinde çalışmış ve Hamparsum'la yazılmış birçok eseri Batı notasına çevirmek suretiyle Türk Müziğine önemli katkılar yapmıştır (Muattar, 2014).

\subsection{Arazbarbuselik Makamının Nazari Özellikleri}

Arazbarbuselik makamı III. Selim tarafından oluşturulmuştur. Makamın dizisi, Arazbar makamı seyrine Buselik beşlisinin eklenmesinden meydana gelir. Bu nedenle Arazbarbuselik makamının anlaşılabilmesi için öncelikle Arazbar makamının karakteristik özellikleri incelenmelidir.

\subsubsection{Arazbar ve Arazbarbuselik Makamlart}

Arazbar makamı inici seyri olan bir makam olup durağı Dügah (la) perdesidir. Dizisi, Nevâ perdesi üzerindeki Beyâti makamı dizisine, Çargâh perdesinde Rast beşlisinin ve yerinde Beyâti makamı dizisine, Çargâh perdesinde Rast beşlisinin ve yerinde Beyâti dizisinin eklenmesi ile meydana gelir. İnici seyre sahip bir makamdır. Makamın seyri Nevâ perdesindeki Beyâti dizisiyle başladığı için birinci derecede güçlüsü Gerdâniye (sol) perdesidir. Üzerinde Buselik çeşnisiyle yarım karar yapılır. İkinci derecede güçlüsü Nevâ perdesidir. Üzerinde Uşşak çeşnisiyle asma karar yapılır. (Özkan, 1994). Bu makam içerisinde yapılabilecek diğer asma kararlar aşağıda listelenmiştir:

- Gerdâniye'de Buselik,

- Gerdâniye'de Hicaz (sık kullanılmaz),

- Acem'de Nikriz,

- Nevâ'da Uşşak,

- Nevâ'da Hicaz (sık kullanılır),

- Çargâh'da Nikriz (sık kullanılır),

- Çargâh'da Rast ve

- Segâh'da Segâh veya Eksik Ferahnâk 
Arazbar makamının seyrinden sonra Dügah (la) veya Çargâh (do) perdesinde kısa bir duruş yapılarak uygun nağmelerle Buselik makamına geçiş yapılır ve yerinde Buselik beşlisi ile karar verilirse Arazbarbuselik makamı icra edilmiş olur. Arazbar ve Arazbarbuselik makamlarının dizileri Şekil 1 ile gösterilmektedir.

\section{Şekil 1}

Arazbar ve Arazbarbuselik Makamları Dizileri
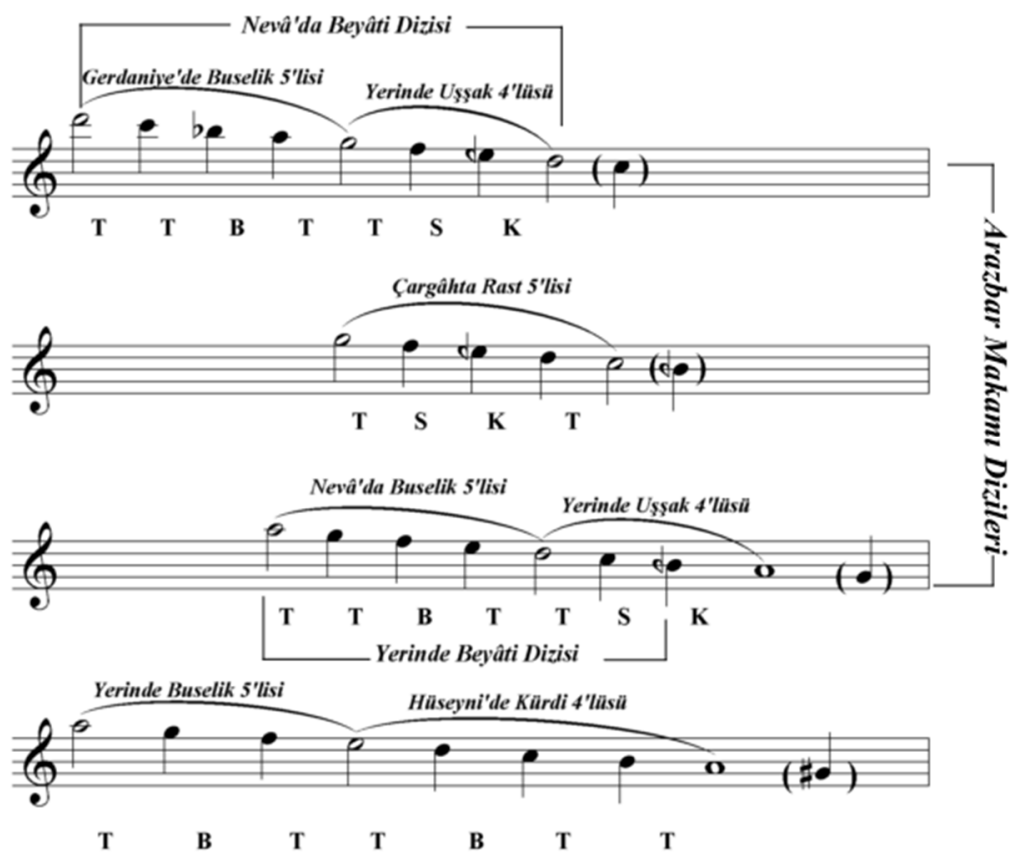

\subsection{Refik Fersan'ın Arazbarbuselik Saz Semaisinin İncelenmesi}

Refik Fersan’ın Arazbar Buselik saz semaisi aslında geleneğin dışında yazılmış bir saz semaisi formundadır. Normalde "tertip" denilen bölüm diğer saz semailerinde yoktur. Saz semaileri 4 hane 1 teslimden oluşmaktadır. Son hanede usul değişikliği yapılır ve mutlaka aksak semai usulünde olması gerekir. Tertip denilen kısım bu esere ilave olarak yapılmış, saz semaisi formunun dışında bir öğedir. Kesin bir kural olmamakla birlikte genelde saz eseri bestekarları çaldıkları enstrümanın bütün teknik zorluklarını besteledikleri eserlere yansıtmışlardır. Bu eserde Arazbarbuselik makamı, Neva perdesinde Uşşak dizisinden daha çok Çargâh perdesinde Rast çeşnisi ile asma kalış yapan bir makamdır. Bu eserde bu özellik fazlasıyla görülmektedir. Eserin notaları incelemesinin yapıldığı hali Ferhat Devecioğlu'nun yazımı ile Ekler bölümünde verilmektedir.

\subsubsection{Birinci Hane}

Eserde 1. Hanenin 1. ölçüsünde makamın ana dizisi içerisinde olmamasına rağmen inici Rast dizisi ile başlanmıştır. 2. ölçüde Gerdaniye perdesinde Buselik çeşnisi yaptıktan sonra Çargâh perdesinde Rast çeşnisi ile yarım karar vermiştir. Bu şekilde makamın ana dizisine dönülmüş olur. 3. ölçüde Çargâh perdesinde Rast ve Yegâh perdesinde Uşşak çeşnileri, 4. ölçüde Rast perdesinde Rast çeşnisi yapıldıktan sonra Çargâh perdesinde Rast çeşnisi ile yarım karar yapılmıştır. 5. ve 6. ölçülerde Çargâh perdesinde Rast başlayarak Neva perdesinde Uşşak ve ardından Gerdaniye perdesinde Buselik çeşnisi yapılarak karar verilmiştir. Tamburda çalınması oldukça zor olan 32'lik notalar eserde fazlaca kullanılmış ve teknik olarak çalınması zor bir eser ortaya çıkarılmıştır.

\subsubsection{Teslim}

Teslimin 1. ölçüsünde do - sol (Çargâh-Gerdaniye) atlaması yaparak Gerdaniye perdesinde Buselik, 2. ölçüde Gerdaniye perdesinde Buselik ve Neva perdesinde Uşşak çeşnileri yapılmıştır. 3. ölçüde Neva perdesinde Uşşak çeşnisi ile başlanıp Neva perdesinde Hicaz yaparak 4. ölçüde Çargâh perdesinde Nikriz 5lisi ile karar vermektedir. 5. ölçüde Neva perdesinde Uşşak 4lüsü ile asma kalış yapılmıştır. 6. ölçüde Uşşak çeşni devam etmektedir (Şekil 2).

\section{Şekil 2}

Teslim 6. Ölçü

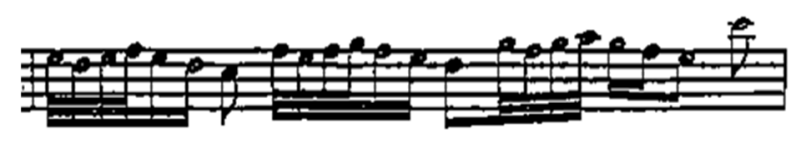


Tamburda üst-alt mızrap kullanmak çok zor olduğundan burada kullanılan nota kalıbı, eserin zorluğunu arttıran bir kalıptır. 7. ölçüde Gerdaniye perdesinde Buselik başlanıp 1/16'lık üçlemelerle bezenmiş tartımlarla Rast perdesinde Çargâh beşlisi ile asma kalış yapılmıştır. 8. ölçüde ise yerinde tam bir Buselik dizisi ile karar verilmiştir.

Bestekar, saz semailerinde birinci hane ve teslimde makamın genel karakteristik özelliğini yansıtmak zorundadır. Bu eserde de birinci ölçü dışında makam çok güzel bir şekilde, makamın karakterine uygun olarak kullanılmıştır. Eser, tamburun çalış tekniğini zorlaması açısından da çok önemli bir eserdir çünkü alt-üst mızrap vuruşları tamburda oldukça zordur. Bu zorluğu yaratabilmek için bestekar 32'lik notaları kullanmıştır. Ardı ardına 13. ölçüde 16'lık triolelerden oluşan sekileme (sekvens), Türk Müziği’nde bugün dahi çok az kullanılan, tamburun tekniğini zorlayıcı bir ajelite ifade eden bir motif biçimidir. Eserde 1,5 - 2 oktava yakın triole ardı ardına kullanılmıştır. Bestekarın tamburi olması sebebiyle tambur üzerindeki zorlukları esere yansıtması gayet doğaldır.

\subsection{3. İkinci Hane}

Bestekar tamamen Batı Müziği motiflerinden etkilenip tambur sazında yapılabilecek teknik olarak en zor hareketleri bu haneye yansıtmıştır. Eserde tiz hüseyni sesine kadar çıkılması tamburun perdelerinin bitiminden sonra gövdeye doğru gelinmesi anlamına gelmektedir. 2. hanenin 1., 2., 3. ve 4. ölçülerinde çeşitli kromatik sesler kullanarak Çargâh makamı dizisi gösterilmiştir. Tamburda çok zor olan aralıklı seslere yer verilmiş, böylece tamburda az kullanılan orta teli fazlaca kullanmak zorunda bırakmıştır. 5. ölçüde Hüseyni Aşiran perdesinde Hicaz Humayun dizisi yapılarak tiz Çargâh perdesinde asma kalış yapılmış, 6. ölçüde 1/16'lık üçlemeler ile aralıklı sesler kullanarak Neva perdesinde Buselik çeşnisi ile kalış yapılmıştır. Esere tambur enstrümanı için çok büyük bir zorluk katılmıştır. 7. ölçüde Rast perdesinde Rast çeşnisi ile başlanıp 8. ölçüde Çargâh perdesinde Çargâh dizisi ile karar verilmiştir. Eserde tüm teknik zorluklarla birlikte ezgi olarak da Batı Müziği ezgilerinin tadı bu haneye yansıtılmıştır. Bu hane Türk Müziğine uyarlanmış Batı Müziği ezgileriyle süslenmiştir. Bestekar tambur çalımına ait tüm teknik zorlukları esere yansıtırken bunu büyük bir melodi zenginliği ve güzelliği içinde Arazbarbuselik makamının seyir anlayışını bozmadan ustalıkla kullanmıştır. Böylece teknik zorluklar ve melodinin verdiği duyguyu aynı hanede başarıyla bir araya toplanmıştır.

\subsubsection{Tertip}

Bu bölüm normalde saz semaisi yapısında çok fazla yer almayan bir bölümdür. Eserde tertip 2., 3. ve 4. hanelerin bitiminde teslimden önce çalınmaktadır. 1. haneden sonra çalınmamasının nedeni, ilk hane ve teslimin bütünlüğünü makamın karakteristik özelliklerini yansıtmada ana unsurlar olması nedeniyle kesintiye uğratmamak içindir. 1. ve 2. ölçüsünde Çargâh perdesinde Çargâh çeşnisi ile 1/16'lık trioleleri art arda kullanarak kalış yapılmış, 3. ölçüde Gerdaniye perdesinde Buselik ve Neva perdesinde Uşşak çeşnileri yapılarak 4. ölçüde Gerdaniye perdesinde Buselik ile karar verilmiştir. Trioleler (üçlemeler) ile bezenmiş ve tambur çalan kişiyi orta teli kullanmak zorunda bırakan tekniği yüksek bölümlerden biridir.

\subsection{5. Üçüncü Hane}

Bu hanede 1. ve 2. ölçüde Hüseyni Aşiran perdesinde Hicaz Humayun dizisi vardır. 3. ve 4. ölçüde aynı şekilde Hüseyni Aşiran perdesinde Hicaz Humayun dizisi ile karar vermiştir. 5, 6, 7 ve 8. ölçülerinde bestekar iki farklı yol izlemiş olabilir. Eviç (fa\#) - Nim Hicaz (do\#) - Nim Hisar (re\#) perdeleri küçük değiştirme işaretleri ile kullanılarak Buselik makamı olarak icra edilmiş ise, bu makamın içerisinde kullanılmayan sesler kullanmış, eğer Hisarbuselik makamı olarak icra edilmiş ise o da tam dizi olarak ifade edilmemiştir. Yine de burada ağırlık altere seslerle kullanılan Buselik makamıdır. Batı Müziği melodi gidişatı bu hanede de özellikle göze çarpmaktadır.

\subsubsection{Dördüncü Hane}

Saz semailerinin son hanelerde mutlaka bir usul değişikliği yapılır. Bestekar burada bu kurala uymuştur. Bu hane usul olarak iki bölümden oluşmaktadır. 1. bölüm 3/4 Semai usulü ile, 2. bölüm ise 7/8 Devri Turan usulü ile bestelenmiştir. 1. ölçüden 8. ölçüye kadar Hüseyni Aşiran perdesinde Hicaz Humayun dizisi, 16. ölçüye kadar olan bölümde ise yerinde Buselik makamı dizisi ile karar verilmiştir. 17 - 24 ölçüleri arasındaki bölüm Rast perdesinde Çargâh dizisi, 25 - 32 ölçüleri arasındaki bölüm Çargâh perdesinde Çargâh dizisidir. 33 - 48 ölçüleri arasındaki bölüm Hisar Buselik makamının tam özelliklerini göstermemekle birlikte bu makamın çeşnisi ile karar vermiştir. 49. ölçüde Devri Turan usulüne geçiş yapılmıştır. Bu ölçüde Çargâh perdesinde Çargâh dizisi ile başlanmıştır. 54. ölçüde Segâh çeşnisinin Hüseyni perdesinde değil, dik Hisar perdesinde olması gerekmesine rağmen duyumsal olarak Hüseyni perdesinde Segâh çeşnisi duyulmaktadır. Bu durum, bu bölümde eserin notalarının yazımının sağlıklı olmayabileceğini düşündürmektedir. 55 - 58. ölçülerinde Çargâh perdesinde Rast dizisi ile karar vermiştir. 59 - 64. ölçüleri arasında dik Hisar perdesinde Müstear çeşnisi yapılmıştır. 65. ölçüde dik Hisar perdesinde Segâh çeşnisi yapılmış, 66. ölçüde ise Segâh makamının Rast perdesine düşme özelliği Çargâh perdesinde kullanılmıştır. 67 - 72. ölçüleri arasında Çargâh perdesinde Çargâh dizisini önce pes, sonra tiz olarak 1 oktav yukarıdan göstermiştir ve "Batak" adı verilen bölüm eklenmiştir. Batak, diğer sazlar dem tutarken bir enstrümanın ezgiyi çalmasıdır (Ayangil, 2013). 73 - 76. ölçüleri arasında Gerdaniye perdesinde Buselik dizisi gösterilmiştir. 77 - 82. ölçüleri arasında Gerdaniye perdesinde Buselik, Nevada Hicaz ve Çargâhta Nikriz çeşnileri 
ile karar vermiştir. Bu hanede de Batı Müziğine ait ezgi motiflerine yer verilmiştir. 4. hanenin semai usulündeki bölümü, 3. hanenin ezgileriyle benzerlik göstermektedir.

\section{Sonuç}

Refik Fersan gerek bestecilik yönü gerekse tambur icrasının gücü bakımından Türk Müziği’ne önemli katkılar yapmış bir bestekarımızdır. Sanatçı pek çok farklı formda ve makamda eserler vererek müziğimizin zenginleşmesinde önemli rol oynamıştır. Bu nedenle bu çalışma bestekarın Arazbarbuselik Saz Semaisi'nin incelenmesini konu edinmiştir. Bu eserin Türk Müziği’ne yapmış olduğu katkılar söyle açıklanabilir:

Eser, Batı Müziği ve Türk Müziği ezgilerinden oluşan çok güzel bir sentezdir. Günümüz sanatçılarına Arazbarbuselik makamının seyri ve içerisinde kullanılan çeşniler ve geçkiler açısından önemli bir örnek teşkil etmektedir. Sadece tambura değil, birçok enstrümanın da sınırlarını zorlayan bir eserdir (klasik kemençe, ney, vb.). Tambur, gelenekte ağırbaşlı çalınan bir enstrüman olmasına rağmen, Cemil Bey ile daha dinamik bir çalım şekli almıştır. Refik Fersan da bu eseriyle tamburu, sazın sınırlarını zorlayan bir noktaya taşımıştır. Ayrıca az kullanılan Arazbarbuselik makamının çok iyi bir şekilde işlenmesi, günümüzdeki sanatçılara ve icracılara makamların daha iyi anlatılması açısından bir örnek oluşturmaktadır. Bestekarın özellikleri incelendiğinde Refik Fersan'ın her formdan eserlerinin bulunması ve bestelediği eserde hem tekniği hem de duyguyu bir arada mükemmel bir şekilde verebilmesi ön plana çıkmaktadır.

\section{Kaynakça}

Abidin, S., \& Çelik, S. (2020). Keman sanatçısı ve bestekâr Hasan Soysal'ın farklı formlardaki ödüllü eserlerinin makam ve usul yönünden incelenmesi. Akademik Sosyal Araştırmalar Dergisi, 7(49), 683-694. http://dx.doi.org/10.29228/SOBIDER.47998

Ak, A. Ş. (2015). Türk musikisi tarihi. (4. Baskı). Akçă̆ Yayınları.

Akçay, T. (2005). Refik Fersan hayatı, eserleri, besteciliği [Yüksek Lisans Tezi, Afyon Kocatepe Üniversitesi]. Wordpress. https://intihalkarlik.files.wordpress.com/2015/09/tugba_akcay_tez_msc_2005.pdf

Ayangil, R. (2013, Mart 11-16). Dönüştürücü bir performans pratiği olarak “batak tekniği” ve saz eserlerinde besteli taksim örnekleri ile icra/yorum tarzları [Konferans sunumu]. Uluslararası Mugam Sempozyumu, Bakü, Azerbaycan. https://tumac.org/donusturucu-bir-performans-pratigi-olarak-batak-teknigi-ve-sazeserlerinde-besteli-taksim-ornekleri-ile-icra-yorum-tarzlari/

Bardakçı, M. (1995). Refik Bey... Refik Fersan ve hatıraları. Pan Yayıncılık.

Başara, E. (2013). Aruz Vezninin Belli Bir Kalıbında Yazılmış Güftelerin Sengin Semâî Usûlü ile Bestelenmesinde Görülen Bazı Prozodik Özellikler. CÜ Sosyal Bilimler Dergisi, 37(2), 41-48. https://dergipark.org.tr/tr/download/article-file/49922

Behar, C. (2008). Musikiden müziğe. Osmanlı/Türk müziği: Gelenek ve modernlik. Yapı Kredi Yayınları.

Bulur, E. (2019). Müzik analizinde Schenker yaklaşımı. Konservatoryum, 6(1), 21-46. https://doi.org/10.26650/ CONS2019-0004

Kaya, F. (2013). Kemençe sazında usta icracılığa yönelik dağar önerileri. E-Journal of New World Sciences Academy, 8(3), 352-365. http://dx.doi.org/10.12739/NWSA.2013.8.3.D0139

Muattar, D. D. (2014). Cumhuriyet dönemi Mevlevî âyini bestekârlarl ve besteleri (Tez No. 369057) [Yüksek Lisans Tezi, Süleyman Demirel Üniversitesi]. Yüksek Öğretim Kurulu Tez Merkezi.

Özcan, N. (1995). Dârülelhan. Diyanet İslâm ansiklopedisi (Cilt 2) (s. 416) içinde. TDV Yayınları.

Özkan, İ. H. (1994). Türk müsıkisi nazariyatı ve usülleri, kudüm velveleri (4. Bask1). Ötüken Neşriyat.

Sadie, S. (2001). The new grove dictionary of music and musicians (Cilt 1). Oxford University Press.

Saraç, G. (1993). Refik Fersan’ın 10 Saz Eserinin Incelenmesi. (Tez No. 26812) [Yüksek Lisans Tezi, İstanbul Teknik Üniversitesi]. Yüksek Öğretim Kurulu Tez Merkezi.

Tüfekçioğlu, S. (2019). Osmanlıda yenilikçi hareketlerle birlikte Türk mûsikîsine eklenen yeni türler ve bu türlerin teori-pratik ikilemi. Atatürk Üniversitesi Güzel Sanatlar Enstitüsü Dergisi, 42, 173-182. https://doi.org/10.32547/ataunigsed.523556 
Ekler

Ek.A Arazbarbuselik Saz Semaisi (Notaya alan Ferhat Devecioğlu)

\section{ARAZBARBUUSELIK SAZ SEMÂAI}
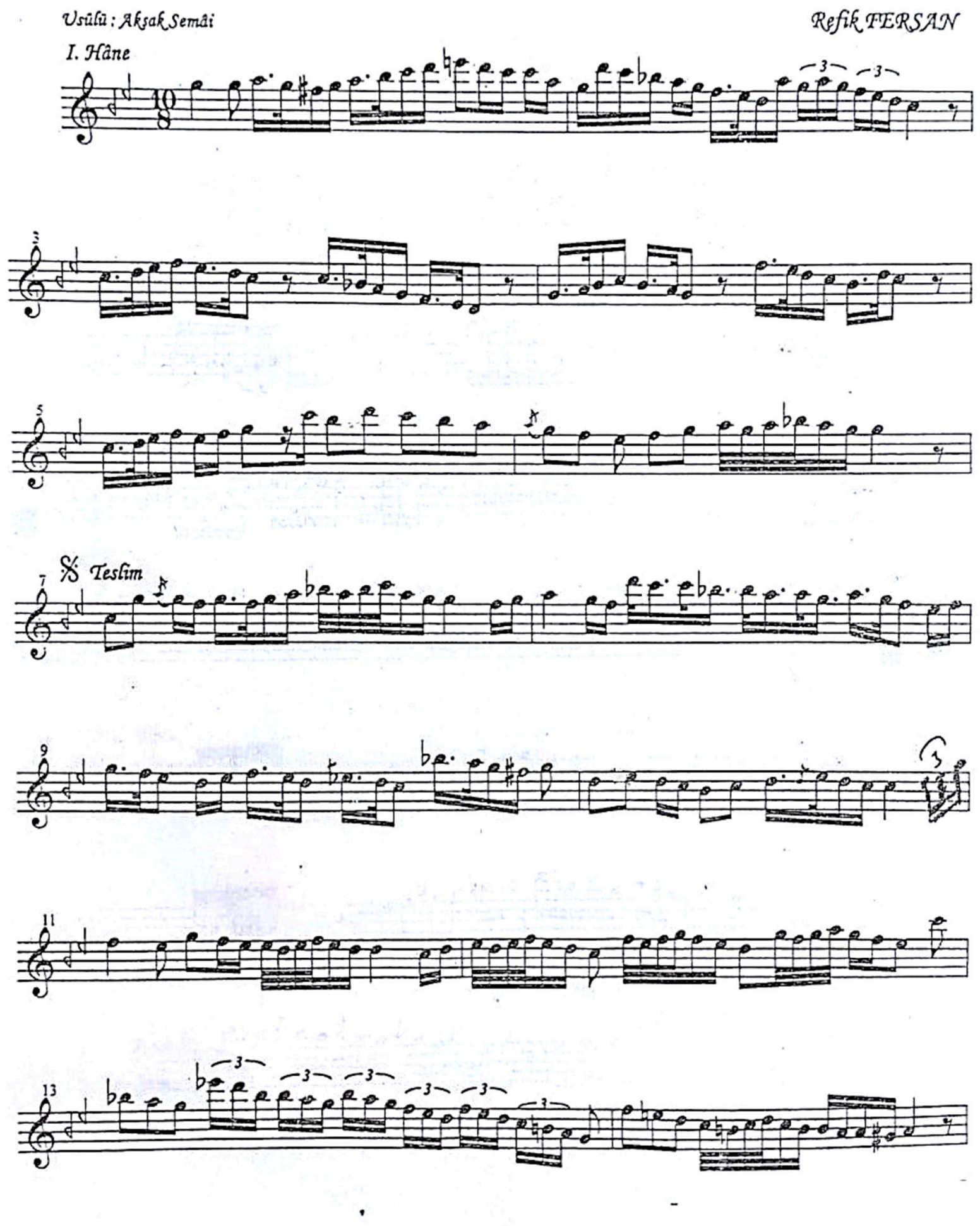

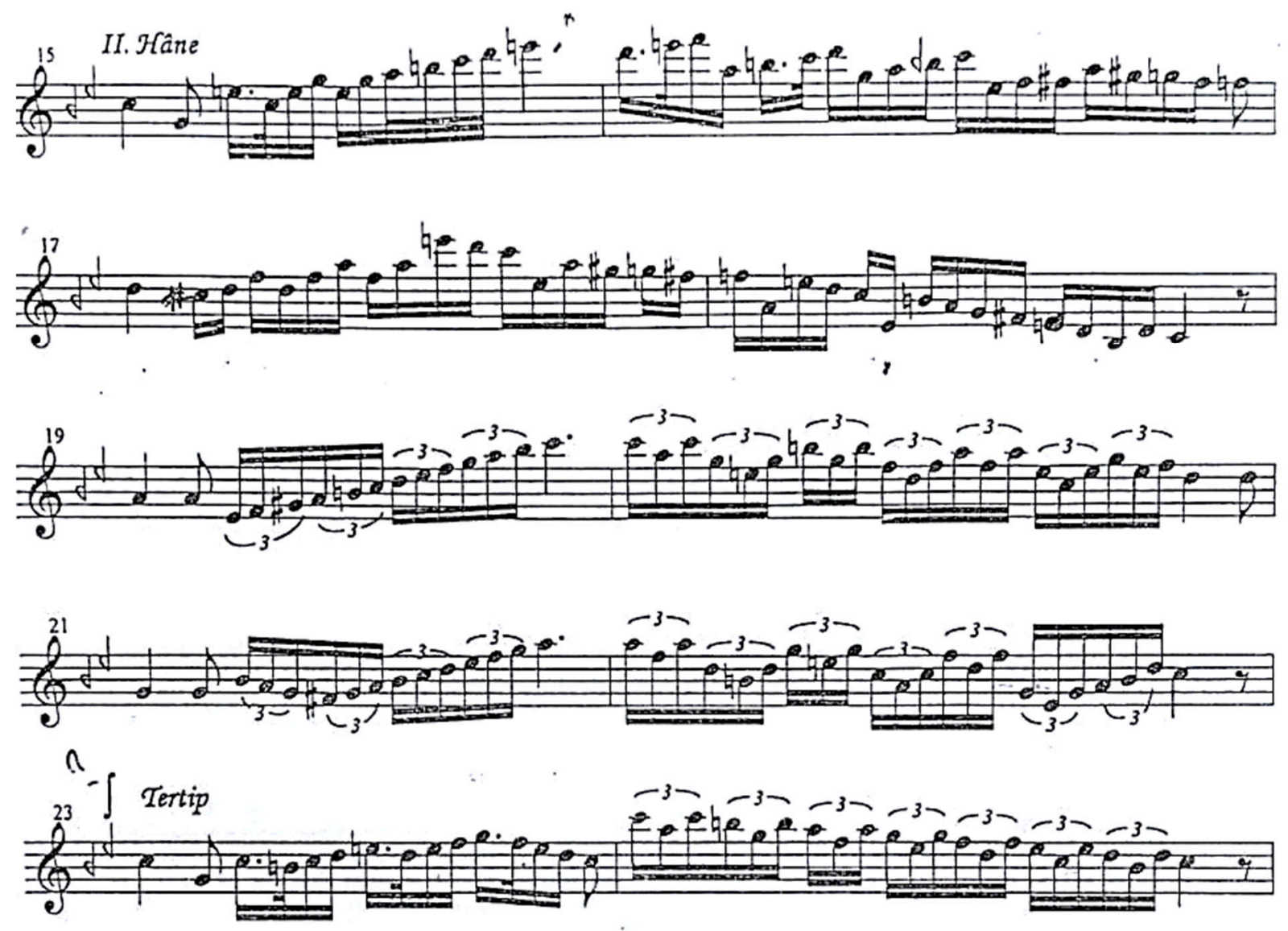

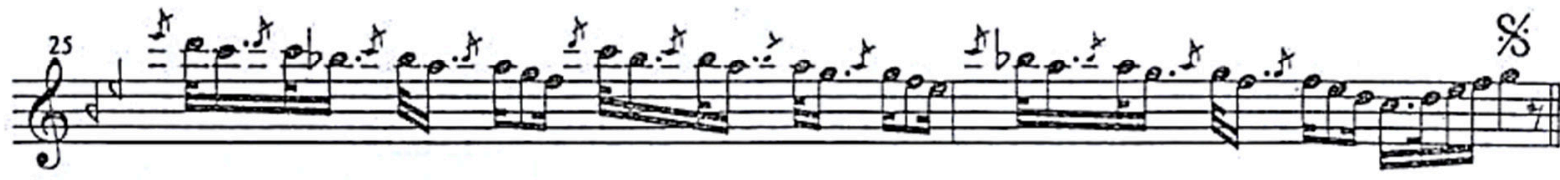
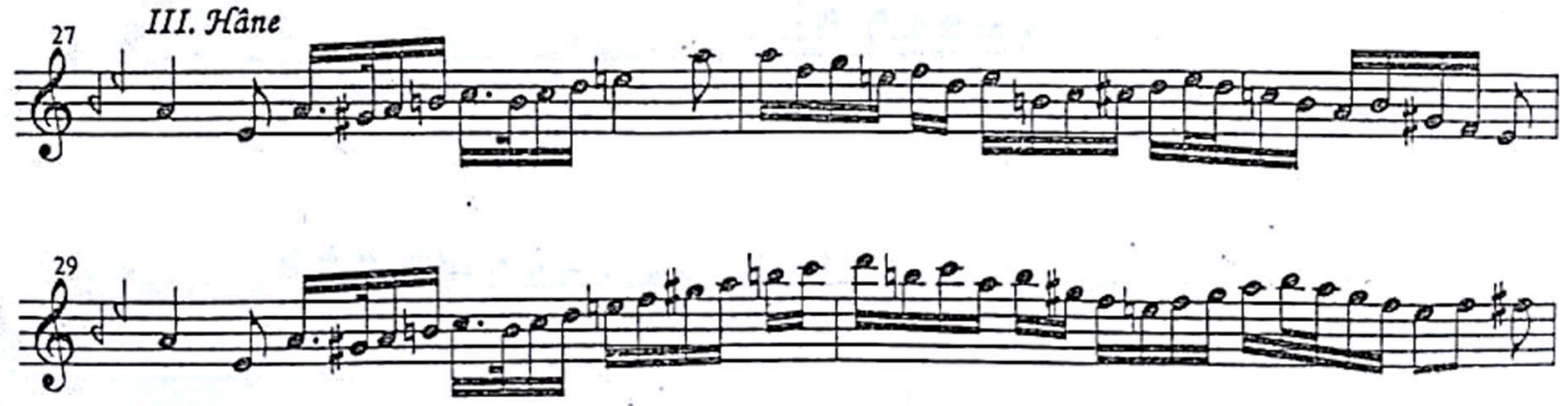

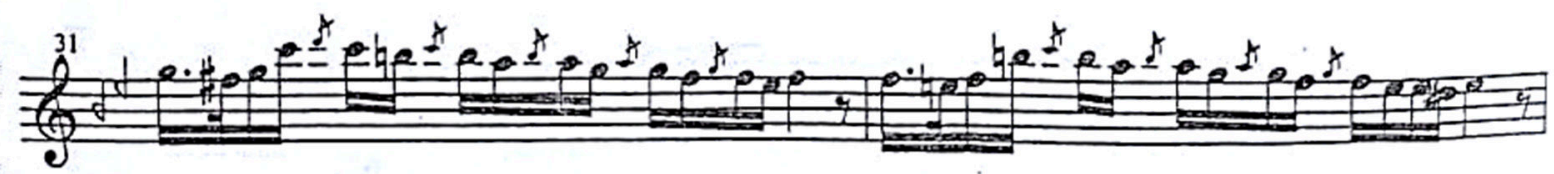



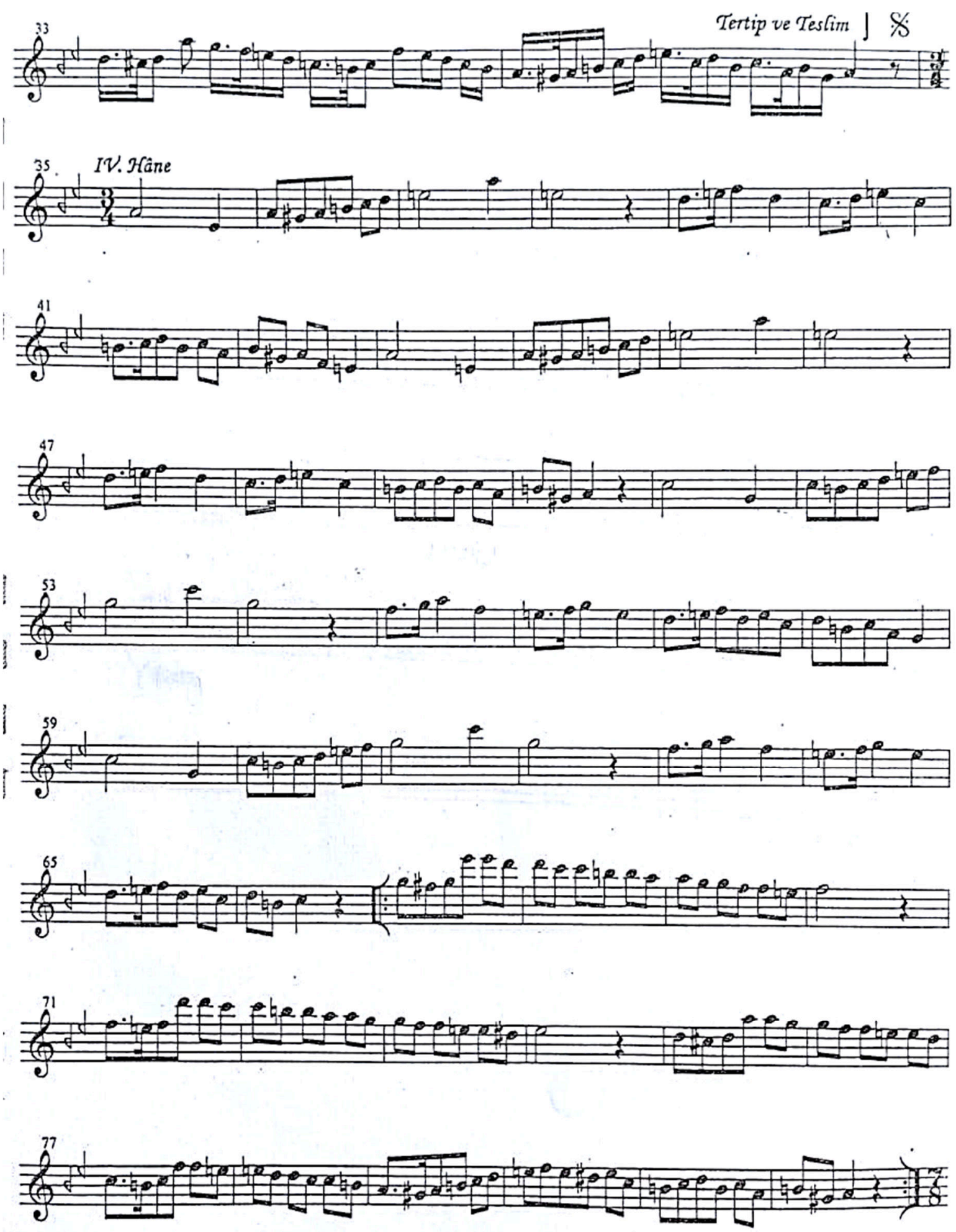
(a)
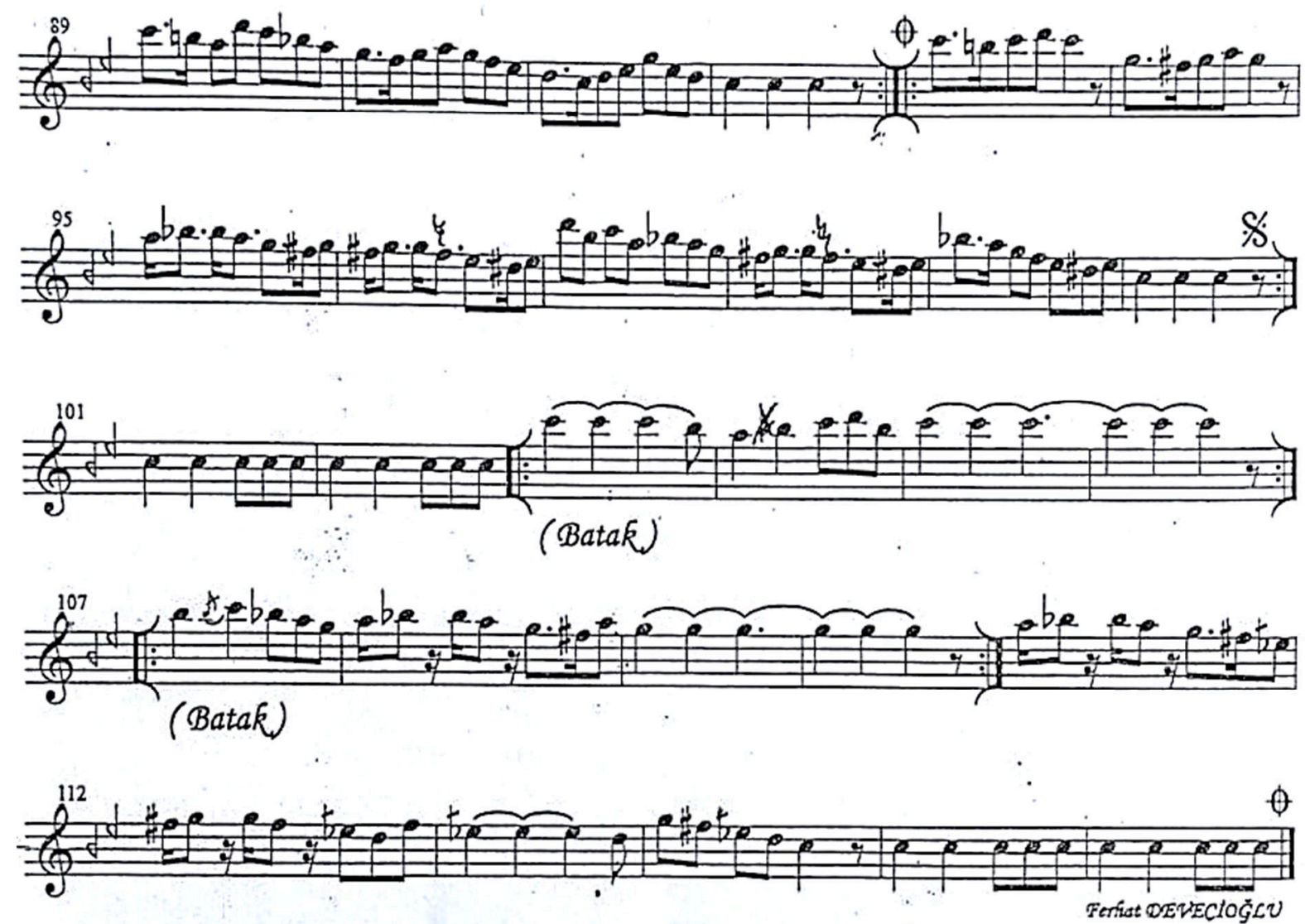